\title{
Interdisciplinary education group in type 1 diabetes
}

\author{
Lucia Hitomi Kamata Lopes*, Cleber Aparecido dos Santos, Mariana Ercole Bauléo, \\ Monica de Cassia Brigeiro Martinez \\ From 20th Brazilian Diabetes Society Congress \\ Porto Alegre, Brazil. 11-18 November 2015
}

\section{Background}

Diabetes mellitus type 1 (DM1) is an autoimmune disease that manifests in childhood or adolescence, promoted by progressive immune-mediated destruction of pancreatic beta cells, resulting in absolute insulin deficiency in the body, which makes patients dependent on insulin. The complexity of the treatment that includes: medication adjustments, nutrition education, blood glucose monitoring and changes in lifestyle habits, factors that lead to difficulty in adherence proposal. The diagnosis affects not only the child but the whole family structure, with impact on the day-to-day and emotional and affective sphere. Education is fundamental to motivate the patient to acquire knowledge and skills promoting self-management of DM1 care generating changes in behavior and better quality of life.

\section{Objective}

To provide better adherence to treatment, disease control and better quality of life by reducing the risk of complications.

\section{Materials and methods}

Monthly educational meetings at a clinic for pediatric specialties, reference to disadvantaged communities of São Paulo, aimed at children with DM1 and their families. The education group in diabetes happens through group education, interactive group, educational games, cooking classes, Practice staff training patients to self-administer insulin, and self-blood glucose monitoring, physical and recreational activities with professionals from an interdisciplinary team (endocrinologist, nutritionist, gastronomy, nurse, psychologist, pharmacist, physical educator and volunteer).

\footnotetext{
* Correspondence: luciahk@einstein.br

Hospital Israelita Albert Einstein, São Paulo, Brazil
}

\section{Results}

Reports of children and their families show that the group not only contributes to the control of the disease but makes a difference in the life of each. "I learned to give more freedom my daughter and so she learned to take care, to apply insulin, have more confidence, be more independent." "I learned to share what I know with others and learned from them too." "In addition to taking questions, it helps to let off steam and have more confidence."

\section{Conclusion}

A multidisciplinary approach, using unconventional therapeutic resources (educational and recreational), if It shows extremely important in diabetes education as a way to increase awareness and acceptance of the disease, through exchanges of experience, technical skills and involvement in decision-making in relation to self-care.

Published: 11 November 2015

doi:10.1186/1758-5996-7-S1-A220

Cite this article as: Lopes et al:: Interdisciplinary education group in type 1 diabetes. Diabetology \& Metabolic Syndrome 2015 7(Suppl 1):A232.

Submit your next manuscript to BioMed Central and take full advantage of:

- Convenient online submission

- Thorough peer review

- No space constraints or color figure charges

- Immediate publication on acceptance

- Inclusion in PubMed, CAS, Scopus and Google Scholar

- Research which is freely available for redistribution 